\title{
Starting the conversation: land issues and critical conservation studies in post-colonial Africa
}

George Barrett, Shirley Brooks, Jenny Josefsson and Nqobile Zulu

\begin{abstract}
This thematic issue brings together the scholarly fields of critical conservation studies and African land issues, a relationship largely unexplored to date. The alienation of land for conservation purposes, introduced to Africa under colonial rule and still taking place today, has fundamental impacts on the politics of land and land use, and is contested in contemporary nation-states - including those that are attempting to implement land restitution and reform. The contributors explore these issues in a range of African contexts. Three key themes are identified: the problematic constructions of 'community' by outside agencies; spatial exclusion and the silencing of local voices; and the neoliberalisation of conservation spaces. In contributing to new perspectives on these themes, this thematic issue shows how discourses and practices of conservation, increasingly shaped by neoliberalism, currently impact on land ownership, access and use. It further highlights some important historical continuities. These trends can be observed in transfrontier conservation areas, on state-owned land used for conservation and 'green' initiatives, but also on private land where conservation is increasingly turned to commercial purposes.
\end{abstract}

\section{Land and conservation in post-colonial Africa: Old Land, New Practices?}

This thematic issue of the Journal of Contemporary African Studies highlights recent scholarship on the complex interrelations between contemporary conservation practices in post-colonial Africa, in conversation with the well-trodden territory of land use and contested land issues in the continent. Within the last two decades or so, a substantial cross-disciplinary literature has emerged that engages with the local and regional politics of nature conservation from a social science perspective (see Anderson and Grove 1987; Neumann 1998; Zerner 2000, 2012, also see Marnham 1980 for an early journalistic critique). Critical conservation studies is emerging as a field in its own right, as evidenced by the success of recent conference initiatives attracting a range of scholars from various disciplines (see for example Nature ${ }^{\mathrm{TM}}$ Inc.). African land issues have been a subject of interest for Africanists over a far longer period, as scholars have grappled with the implications of communal tenure systems, land dispossession and the introduction of private property regimes in southern Africa's settler colonies (Allan 1965; Palmer and Parsons 1977; Bassett and Crummey 1993; Berry 1993; Evers, Speirenburg, and Wels 2005; Derman, Odgaard, and Sjastaad 2007; Benjaminsen and Lund 2012). 
While nature conservation practices inevitably raise challenging questions relating to land and land use, there has thus far been little concentrated effort to bring together scholars working on the land question with those whose work has focused mainly on questions of nature construction and the social impacts of conservation in an African context. A conference held in Grahamstown in September 2012 was conceptualised with the aim of bringing together these two groups of scholars - as well as conservation practitioners - in productive, if at times challenging debate. Titled: 'Old Land, New Practices? The Changing Face of Conservation and Land-Use in Post-Colonial Africa', the meeting was jointly organised by a group of academics and postgraduate students with support from Rhodes University, the University of the Free State and the University of the Witwatersrand. The articles in this thematic issue were first presented as papers at this conference. The scope of interest includes the maintenance and extension of existing state-run conservation areas, new land allocations for conservation, the impacts of various forms of 'community-based conservation' and associated landuse controls in communal areas; as well as conservation enterprises on privately owned land and theimpacts and outcomes ofland reform.

Before introducing the articles in more detail, it is useful to reflect briefly on the focus and significance of the theme under review. The title of the conference implied a question with which contributors grappled - that is, the extent to which 'new' practices reflect discontinuity and a departure from the past, and whether qualitative shifts in practice are actually taking place or not. It is common cause that the alienation of land for conservation purposes, introduced to Africa under colonial rule, has continued more or less uninterrupted until today - albeit with the participation of different actors, under different circumstances and employing different pretexts. The many continuities in nature conservation, and the difficulties of 'decolonising conservation' in contexts where essentially colonial views of nature and its role still prevail in much policy and practice, are now quite well documented (see Adams and Mulligan 2003; Brockington and Igoe 2006). In southern Africa, the persistence after the end of apartheid of structures that govern conservation, as well as the people who are represented in these structures, is one example (see Draper, Speirenburg, and Wels 2004).

Other work, however, does suggest a qualitative shift. This thematic issue highlights a growing body of research showing how the discourses around nature, protected areas and wildlife have changed alongside a general mainstreaming of 'green' issues (Brockington and Duffy 2010; MacDonald 2010). In market-oriented approaches to conservation, a protected area is made to 'pay for itself' by identifying a niche and a value of some sort within a global marketplace increasingly well stocked with marketable nature and environmental initiatives (Büscher and Arsel 2012; Igoe, Neves, and Brockington 2010). This approach finds support in discourses of sustainable development and ecological modernisation, widely incorporated - at least at the level of rhetoric - into political and corporate agendas (MacDonald 2010). Such trends have developed as a result of (and in conjunction with) the neoliberalisation of political and economic ideologies and practices in the past four decades, where nature and conservation too are undergoing a process of neoliberalisation. This represents a significant shift in the ideologies of nature conservation and environmentalism, where 'nature' was originally conceptualised as a sphere 
requiring protection from economic forces (Brockington and Duffy 2010; also see Ramutsindela and Shabangu 2013, this issue). Utilisation and privatisation of natural resources, as well as the idea of a conservation area as a 'resource', are now normalised into policy and management practices. The commodification of nature is viewed as necessary for sustaining its existence, and vice versa -the use of nature and natural resources is proposed as a key to ending the current financial crisis (Igoe, Neves, and Brockington 2010).

The increasing commodification of life in all its forms is also reflected in the proliferation of 'transfrontier parks', known in the southern African context as 'peace parks'. These extend the reach of conservation practices into land that may formerly have been under different governance structures, and in the process create new security apparatus for protecting land. The development of southern African peace parks has provoked a growing inter-disciplinary critique. One focus is the implications of their development for state sovereignty and security in a region with a troubled history of inter-state relations (Duffy 2001, 2007; Ramutsindela 2007). It is not coincidental that the parks are located in border zone spaces where states have always had to assert their authority and delineate control (see Barrett 2013, this issue). Peace parks are ascribed the potential to bring greater security to the region and its people, particularly people who have historically and geographically been marginalised and located on the periphery of the state. However, the preoccupation with state-centric security concerns means that the security implications for actors other than the state are frequently obscured. Moreover, the pursuit of such aspirations within a neoliberal framework seems to (re)produce and exacerbate past experiences of insecurity and exclusion.

One way to bring the field of land and agrarian studies into closer proximity with critical conservation studies is for scholars in the latter field to pay more detailed attention to the wayland tenure regimes influence and shape conservation practices in different contexts. Land held under indigenous or 'communal' tenure, or by land trusts, enables the promotion and implementation of various forms of conservation 'partnership' between state and private actors and so-called 'communities' (see for example, Ngubane and Brooks 2013, this issue; Godfrey 2013, this issue). Interventions by the state in land tenure (generally through various land reforminitiatives, for example in post-apartheid South Africa) create new contexts for conservation practices such as comanagement. While land held under freehold tenure is arguably less accessible than communal land to state conservation policies - although in the post-colonial context of southern Africa this ownership does not always go unchallenged - conservation authorities have embarked on stewardship programmes with the aim of attracting private landowners to adopt conservation-friendly management practices (for examples from South Africa, see CapeNature and Ezemvelo KZN Wildlife websites). These strategies aim to secure land for conservation in contexts where the state's options for acquiring new land are becoming more limited -at the same time, providing poor people with a viable land-use option, at least in theory.

More recently, attention has been drawn to the worldwide phenomenon of land grabbing, where often communally owned lands in the global South are acquired through a range of means (corrupt and otherwise) by large multinational corporations for commercial purposes. These include mining, the production of biofuels and food production for citizens of land-hungry 
northern countries (see Hall 2011; Borras et al. 2011; Borras and Franco 2012). Obviously colonialism itself was an ambitious and far-reaching form of land grab, and it is interesting to reflect on the differences between colonial 'land grabs' and today's version. Of particular interest to the theme of this special issue is the aspect of the so-called land grabbing phenomenon characterised as 'green grabbing'. Emerging scholarship on 'green grabbing' resonates strongly with the neo-liberalisation processes mentioned above in the context of new conservation practices. In a definition recently offered by Fairhead, Leach, and Scoones (2012, 237), the term 'green grabbing' describes contemporary forms of the 'appropriation of land and resources for environmental ends'. What makes it qualitatively different from past forms of colonial environmentalism, in their view, is that it 'involves novel forms of valuation, commodification and markets for pieces and aspects of nature, and an extraordinary new range of actors and alliances' (Fairhead, Leach, and Scoones 2012). The phenomenon of 'green grabbing' is thus gaining increasing prominence as a form of land and resource grab that involves 'new forms of appropriation of nature' (Fairhead, Leach, and Scoones 2012), leading to the restructuring of agrarian social and economic relations in Africa and elsewhere.

\section{Introducing the articles: key themes and critical debates}

The ninearticles in this thematicissue, written from different disciplinary viewpoints, have important contributions to make to the debates highlighted above. As far as geographical range is concerned, the authors have worked in South Africa, Zambia, Uganda and Mauritius, suggesting common themes that extend well beyond the borders of a single country. Three broad groupings of papers are identified here, even though these themes are of course overlapping and some articles address more than one theme.

The first grouping of articles focuses on the often troubling politics through which 'communities' are constructed by conservation authorities, donor organisations and others involved in partnerships and (co)management of conservation areas as well as in land reform. A second set of articles speaks to the imposition of conservation management in particular spaces and issues of denied or excluded spatialities. Part of this story is the disallowing of resource use practices considered inappropriate under environmental governance regimes, and the effective silencing of dissenting local voices. 'Hidden' contestations over land and land use in these contexts are brought into the open, demonstrating how power operates in the exertion of control over land. The last group of papers deals most explicitly with the related theme of the neoliberal reconceptualisation of African nature and its (expanding) protected areas. These articles address questions around the neoliberalisation of conservation and environmentalism, and the commodification of nature through the positioning of transfrontier parks and other protected areas in the 'nature market' as well as so-called green economy initiatives such as carbon sequestration.

\section{Constructing the 'community'}

Godfrey's article paints a disturbing picture of top-down approaches to resource conservation and the ongoing construction of a 'mythic community' on the borders of South Luangwa National Park, Zambia. Her research, recalling many similarly top-down development programmes in Africa, reveals continuities between colonial and post-colonial discourses organised in fields of power that work to

\section{http://repository.uwc.ac.za}


deny the rural poor not only their past but also, in a sense, their future. The article provides a powerful critique of the waves of apparently 'newly minted' community-based conservation initiatives imposed on local people by donor organisations, all taking a similar 'blueprint' approach and equally blind to the specificities of particular groups and histories.

This process of homogenisation and misrepresentation by outside promoters of conservation is also evident in Ngubane and Brooks' research on the creation of new 'community game farms' through the land reform process in KwaZulu-Natal, South Africa. In similar fashion to Godfrey, they address the complexities of 'community construction' and link this to a biodiversity conservation discourse that (re)constructs the identity of land beneficiaries as a single homogenous group. Their article further draws attention to the new power relations that arise from land restitution and the impact on land beneficiaries. Game farming is itself a 'new practice' on 'old land', as many freehold farms in different parts of southern Africa move from conventional areas of agricultural land use such as cattle farming, to wildlife production (in this case hunting farms) - a trend that has shown significant growth in the South African countryside in the last few decades (see Snijders 2012). The emergence of the 'communitygame farm' is a new twist to this tale.

Den Hertog's article on the !Xun and Khwe groups in South Africa is likewise sensitive to the construction of 'community', again in the context of land reform. Den Hertog examines the impacts of an involuntary amalgamation of two distinct groups, the !Xun and Khwe, into a uniform 'community' with one collective identity. One consequence of this construction - first created in the 1960 and since then reinforced a number of times -is an imposed sharing of space, most recently resulting from land redistribution. Like Brooks and Ngubane, den Hertog is concerned that current attempts by outside role-players to define 'community' identities, needs and aspirations continue to rely on colonial and apartheid classifications and stereotypes.

\section{Spatialities of exclusion and silenced voices}

Olivier's article draws attention to voices generally unheard or silenced through environmental governance practices in protected areas. The article addresses 'hidden' contestations over land and resource use in the Boland area of South Africa's Western Cape Province. Olivier tackles the paradox of how organisations, and in particular conservation authorities in the region, deal with a group of people known as 'bossiedokters', health practitioners who are generally denied access to the protected areas they need to access. This appears to belie promises of greater openness and more local participation in decision-making around protected areas in the post-apartheid era; the broader context of land reform seems to have little impact on established conservation practices, which continue to prioritise environmental management governance regimes in protected areas.

On the other side of the country, in the KwaZulu-Natal province, Hansen's work is also intended to render audible marginalised voices drowned out by the conceptions and practices of state agencies at the Isimangaliso Wetland Park, a world heritage site. In her article, Hansen uses Lefebvre'sinfluential ideas about the production of space to think through hidden spatialities that are not taken into account by those responsible for the park's governance. Like Olivier, she brings to the surface contestations over conservation space and the consequences of biodiversity conservation regimes for local people. Hansen also comments on the consequences of the neoliberal 
conservation ideology adopted by park authorities for everyday life and livelihood practices in the area.

While not specifically addressing conservation space, the article by Salverda makes a useful contribution in discussing the persistence of colonial forms of land ownership in post-colonial Africa. Questions about elite and exclusive control of space in the form of private land tenure remain uncomfortable in many former settler colonies. Salverda's subject is the persistence of unequal land distribution on the island state of Mauritius. The article highlights in particular the ambiguous position of the old Franco-Mauritian landowning elite who remain in control of their estates. In general, landowners are able to defend their position through an uneasy collaboration with the public and private sectors, who wish to safeguard the island's image as a stable state and an attractive tourist destination. However, as Salverda shows, at times the landowning elite has been confronted with its colonial past and has strategically surrendered parts of their land.

\section{The neoliberalisation of conservation spaces}

Like the articles discussed under the previous theme, Barrett's work on peace parks in southern Africa also provides new insights into the spatiality of conservation, especially the (ongoing) securitisation of border zones. She also shows how the peace park vision partakes in the processes of neoliberal nature commodification. As Barrett argues, the peace park vision is constructed around a notion of 'exceptionalism', as the parks are marketed around the idea of exceptional landscapes, wildlife and people. In the process commodified identities are assigned to the landscapes, wildlife and people within the park borders, and people who do not fit into the vision become more vulnerable. Under the neoliberal conservation paradigm, the border zones remain as spaces of physical and symbolical exclusion - and not 'spaces of opportunity', as argued by peace parks advocates. The complex realities of the parks tend to be obscured by 'logical' and 'effective' marketbased solutions. As in the case of the 'bossiedoktors' (Olivier 2013, this issue), there is a silencing of displaced groups whose identities and histories are overshadowed by the parks' conception and governance practices.

The neoliberalisation of nature and conservation is also a key theme in Ramutsindela and Shabangu's article on state protected areas and land reform in South Africa. The politics of land and agrarian relations are inseparable from the neoliberalisation of nature and the alignment of conservation and business interests - with significant effects on the outcome of land claims. In their analysis of the famous Makuleke land claim in the Kruger National Park, Ramutsindela and Shabangu offer a fresh perspective on why this initially celebrated example of land restitution has not been repeated in the case of other land claims on state protected areas. The specific timing and political circumstances of the settlement solution (later known as the Makuleke model) help to explain its perceived success, but neoliberal influences on tourism policies and conservation agendas, it is argued, contributed to a perception of the model as a threat to the park and the planned transfrontier conservation area.

The last paper, by Nel and Hill, traces the way local people in Uganda, East Africa, are being sidelined in their own spaces by new land-use practices around carbon sequestration. In a now familiar theme, development efforts are negotiated by the state in a top-down approach that also

\section{http://repository.uwc.ac.za}


draws in collaborating agents. Whilethe article focuses on the very recent phenomenon of carbon forestry in East Africa, it highlights the continuities of colonial to post-colonial histories of land grabbing, 'green grabbing' and the politics of resource extraction. This article begins to suggest some of the ways that resources of (often marginalised) people in the South are being re-imagined under the paradigm of the current ecological and economic crisis, and acquired for increasingly global commodity markets - perhaps characteristic of trends that constitute the 'new face' of conservation and land politics in Africa.

\section{Acknowledgements}

The Guest Editors would like to extend their gratitude to academics and practitioners integral to the development and success of the Old Land, New Practices conference, not least Prof. Bram Bü scher of the International Institute of Social Studies, the Hague; Saliem Fakir, Head of the Living Planet Unit of WWF South Africa and Prof Fred Hendricks, Dean of Humanities at Rhodes University. Particular thanks go to Prof Maano Ramutsindela from the Department of Environmental and Geographical Science at the University of Cape Town for his rigorous engagement, support and advice before and during the conference and crucially in the development of this thematic issue. We would also like to extend our thanks to the reviewers who provided constructive critique to the authors to transform their conference papers into publishable articles. Finally we would like to thank the following individuals and institutions for their financial support and contributions to making the Old Land, New Practices conference possible: Rhodes University Research Office and the Dean of Humanities, Fred Hendricks; the Faculty of Humanities and the School of Social Sciences, University of the Witwatersrand, in particular its former Dean Prof. Tawana Kupe and Prof. Philip Bonner who holds the NRF Chair in History; and finally the Dean of the Faculty of Natural and Agricultural Sciences, Prof. Neil Heidemann, and the Department of Geography (especially Prof. Peter Holmes and Dr. Charles Barker) at the University of the Free State.

\section{Notes on contributors}

George Barrett is a lecturer and $\mathrm{PhD}$ candidate in the Department of Political and International Studies at Rhodes University. Her main research interests include critical security studies, environmental politics and ethics, and an international political sociology of security, specifically ways in which neoliberal market capitalism and the commodification of life are creating and recreating processes of inclusion and exclusion, security and insecurity. George is also part of the Thinking Africa research and teaching programme which seeks to promote African theory and scholarship both within the continent but also on the international stage.

Shirley Brooks is a Human Geographer whose research and teaching has focused on environmental history, critical conservation and land issues. She is currently Associate Professor at the Department of Geography and Environmental Studies at the University of the Western Cape, having worked previously at the Universities of the Free State and KwaZulu-Natal. Shirley has written extensively on the history of protected areas and her current research focuses on the socio-spatial impacts of private wildlife production or game farming. 
Jenny Josefsson is a PhD candidate in the Geography Department at University of the Free State. Her research interests include tensions between conservation and development, constructions of nature and the relationships between land, identities and power. Her doctoral research explores the impacts of conversions of cattle farms to private game farms on farm dwellers, and how they respond to these changes. This research is part of a NWO-WOTRO Programme called 'Farm Dwellers, the Forgotten People? Consequences of Conversions to Private Wildlife Production in KwaZulu-Natal and the Eastern Cape'.

Nqobile Zulu is a $\mathrm{PhD}$ candidate in Development Studies at the University of Witwatersrand. He is also a tutor in Sociological Theory. His research interests span across the spectrum of agrarian reform and the interface it brings to rural communities and development issues, gender and health perspectives. Nqobile is presently researching and writing his $\mathrm{PhD}$ on the transition from pastoral to game farming and ranching in the Groot Marico district of the North West province in South Africa. 


\section{References}

Adams, William M., and Martin Mulligan, eds. 2003. Decolonizing Nature: Strategies for Conservation in a Post-Colonial Era. London: Earthscan.

Allan, William. 1965. The African Husbandman. London: Oliver \& Boyd.

Anderson, David, and Richard Grove, eds. 1987. Conservation in Africa: People, Policies and Practice. New York: Cambridge University Press.

Barrett, George. 2013. "Markets of Exceptionalism: Peace Parks in Southern Africa." Journal of Contemporary African Studies. doi:10.1080/02589001.2013.808876.

Bassett, Thomas J., and Donald E. Crummey, eds. 1993. Land in African Agrarian Systems. Wisconsin: University of Wisconsin Press.

Benjaminsen, Tor A., and Christian Lund, eds. 2012. Securing Land Rights in Africa. 2nd ed. London: Routledge.

Berry, Sara S. 1993. No Condition is Permanent: The Social Dynamics of Agrarian Change in Sub-Saharan Africa. Madison: The University of Wisconsin Press.

Borras, Saturnino M. Jr., and Jennifer C. Franco. 2012. "Global Land Grabbing and Trajectories of Agrarian Change: A Preliminary Analysis." Journal of Agrarian Change 12 (1): 34-59. doi:10.1111/j.1471-0366.2011.00339.x.

Borras, Saturnino M. Jr., Ruth Hall, Ian Scoones, Ben White, and Wendy Wolford. 2011. "Towards a Better Understanding of Global Land Grabbing: An Editorial Introduction." The Journal of Peasant Studies 38 (2): 209-216. doi:10.1080/03066150.2011.559005.

Brockington, Dan, and Jim Igoe. 2006. "Eviction for Conservation - A Global Overview." Conservation and Society 4 (3): 424-470. doi:10.1111/j.14678330.2010.00760.x.

Brockington, Dan, and Rosaleen Duffy. 2010. "Capitalism and Conservation: The Production and Reproduction of Biodiversity Conservation." Antipode 42 (3): 469-484. doi:10.1111/ j.1467-8330.2010.00760.x.

Bü scher, Bram, and Murat Arsel. 2012. "Introduction: Neoliberal Conservation, Uneven Geographical Development and the Dynamics of Contemporary Capitalism." Tijdschrift voor Economische en Sociale Geografie 103 (2): $129-135$. doi:0.1111/j.1467-9663.2012. 00712.x.

CapeNature Stewardship Programme. Stewardship. Accessed April 9, 2013. http://www. capenature.co.za/projects.htm?sm[p1][category] $=444$.

Derman, Bill, Rie Odgaard, and Espen Sjastaad, eds. 2007. Conflicts Over Land and Water in Africa: Cameroon, Ghana, Burkina Faso, West Africa, Sudan, South Africa, Zimbabwe, Kenya, Tanzania. West Lansing: MSU Press.

Draper, Malcom, Marja Spierenburg, and Harry Wels. 2004. "African Dreams of Cohesion: Elite Pacting and Community Development in Transfrontier Conservation Areas in Southern Africa." Culture and Organization 10 (4): 341353. doi:10.1080/1475955042000313777.

Duffy, Rosaleen. 2001. "Peace Parks: The Paradox of Globalisation." Geopolitics 6 (2): 126.doi:10.1080/14650040108407715. 
Duffy, Rosaleen. 2007. "Peace Parks and Global Politics: The Paradoxes and Challenges of Global Governance." In Peace Parks: Conservation and Conflict Resolution, edited by S. H. Ali, 55-68. London: MIT Press.

Evers, Sandra, Marja Spierenburg, and Harry Wels, eds. 2005. Competing Jurisdictions: Settling Land Claims in Africa. Leiden: Brill Academic.

Ezemvelo KZN Wildlife Stewardship Programme. Stewardship. Accessed April 9, 2013. http:// www.kznwildlife.com/index.php/conservation/stewardship.html.

Fairhead, James, Melissa Leach, and Ian Scoones. 2012. "Green Grabbing: A New Appropriation of Nature?" The Journal of Peasant Studies 39 (2): 237-261. doi:10.1080/03066150.2012.671770.

Godfrey, Elizabeth. 2013. "Peanut Butter Salvation: The Replayed Assumptions of 'Community' - Conservation in Zambia." Journal of Contemporary African Studies. doi:10.1080/ 02589001.2013.804245.

Hall, Ruth. 2011. "Land Grabbing in Southern Africa: The Many Faces of the Investor Rush." Review of African Political Economy 38 (128): 193-214. doi:10.1080/03056244. 2011.582753.

Igoe, Jim, Katja Neves, and Dan Brockington. 2010. "A Spectacular Eco-Tour around the Historic Bloc: Theorising the Convergence of Biodiversity Conservation and Capitalist Expansion." Antipode 42 (3): 513-550. doi:10.1111/j.1467-8330.2010.00761.x.

MacDonald, Kenneth I. 2010. "The Devil is in the (Bio)diversity: Private Sector 'Engagement' and the Restructuring of Biodiversity Conservation." Antipode 42 (3): 513-550. doi:10.1111/j.1467-8330.2010.00762.x.

Marnham, Patrick. 1980. Fantastic Invasion: Notes on Contemporary Africa. London: Jonathan Cape.

Nature ${ }^{\mathrm{TM}}$ Inc. Questioning the Market Panacea in Environmental Policy and Conservation. Accessed April 2013. http://www.iss.nl/research/conferences_and_seminars/previous_ iss_conferences_and_seminars/naturetm_inc_questioning_the_market_panace a_in_environmental_policy_and_conservation/.

Neumann, Roderick P. 1998. Imposing Wilderness: Struggles over Livelihood and Nature Preservation in Africa. Berkeley: University of California Press.

Ngubane, Mnqobi, and Shirley Brooks. 2013. "Land Beneficiaries as Game Farmers: Conservation, Land Reform, and the Invention of the "Community Game Farm' in KwaZulu-Natal." Journal of Contemporary African Studies. doi:10.1080/02589001.2013. 811790.

Olivier, Lennox. 2013. "Bossiedokters and the Challenges of Nature Co-management in the Boland Area." Journal of Contemporary African Studies. doi:10.1080/02589001.2013.804246. Palmer, Robin, and Neil Parsons, eds. 1977. The Roots of Rural Poverty in Central and Southern Africa. Berkeley: University of California Press.

Ramutsindela, Maano. 2007. Transfrontier Conservation in Africa: At the Confluence of Capital, Politics and Nature. Wallingford: Cabi. 
Ramutsindela, Maano, and Medupi Shabangu. 2013. "Conditioned by Neoliberalism: A Reassessment of Land Claim Resolutions in Kruger National Park." Journal of Contemporary African Studies. doi:10.1080/02589001.2013.811791.

Snijders, Dhoya. 2012. "Wild Property and its Boundaries - on Wildlife Policy and Rural Consequences in South Africa." The Journal of Peasant Studies 39 (2): 503-520. doi:10.1080/03066150.2012.667406.

Zerner, Charles, ed. 2000. People, Plants and Justice: The Politics of Nature Conservation. New York: Columbia University Press.

Zerner, Charles, ed. 2012. People, Plants and Justice: The Politics of Nature Conservation. 2nd ed. New York: Columbia University Press. 